\title{
Traditional Polish lullabies
}

\author{
Kazimierz Sikora \\ Barbara Żebrowska
}

\begin{abstract}
The present article brings an introductory, linguistic and ethnolinguistic description of Polish folk lullabies, taking into account the stylistic and pragmalinguistic features as well as genre rules of these unique songs targeted at children. Nearly 70 authentic texts were analysed for the study. The authors believe it is worthwhile to look at folk lullabies since they retain numerous archaic elements, including features which are prototypical of this ancient genre of melic poetry. Apart from that, they seem to come closest to the instinctive behaviour of a mother wishing to put her child to sleep, and present the first examples of lullabies as we know them today.
\end{abstract}

Keywords: Polish folk lullaby, folk genre rules, functions of folklore, lullaby strategies

\section{Introduction}

All nations and communities know the practice of singing over a child who is falling asleep. Lullabies are created and performed in an instinctive and intuitive way. They are primeval, although not eternal, and indeed today they are disappearing, being replaced by radio music and CDs. The lullaby is falling into oblivion together with the willingness to sing every day. Singing that would accompany daily activities as well as strong family traditions are passed on from generation to generation. It is disappearing because it is ancient and to young people (who are now parents) singing lullabies to their children seems archaic and anachronistic.

The lullaby is a unity comprising of music and words. It has a salient functional form, and physiologically and pragmatically natural origin. It is one of the prototypical oral genres of children's literature and folk melic poetry, side 
by side with the counting songs or poems. It is a border area between literature and folklore; a syncretic genre linking linguistic, musical, psychological and cultural aspects (cf. Jeziorkowska-Polakowska 2010). The lullaby usually constitutes the infant's first contact with poetry and music, even before he or she starts speaking. The folk lullaby has been a constant source of inspiration for many varieties of lyrical poetry for children. Many lyrical Polish carols such as Lulajze Jezuniu ('Sleep well, little Jesus') are based on the genre of folk lullabies. It also has other numerous artistic continuations such as the famous lullaby by Krzysztof Komeda from the film "Rosemary's baby“, directed by Roman Polański. The texts of lullabies were transmitted orally, and always by being sung, hence their formulaity and the presence of very many variants (see also Sarv 2013, this volume, about improvisation in folk lullabies).

On the whole, Polish scholars have paid little attention to lullabies. This has stemmed from their irrational conviction that lullabies are a permanent feature of all cultures. Because of the lack of interest in collecting lullabies, they have never become a subject of serious research in Polish; many of them have been forgotten and today it is very difficult to find reliable informers for collecting lullabies. The lack of ready scholarly studies makes interested researchers seek for information about lullabies from various places, sometimes finding only very insufficient pieces of material.The primeval nature and prototypicality of lullabies encourage researchers to undertake comparative studies ${ }^{1}$. We will start from presenting three selected examples of Polish folk lullabies ${ }^{2}$.

1 This article will address only Polish lullabies; only selected problems of their structure and pragmatics will be discussed here.

2 We have drawn the texts from the radio archive recordings avalable as a series of CDs as part of the Polish radio folk collection - Sources of Polish folk music. Later in the text we use the identifying abbreviation PRFolkColl+No of the CD. As a sidenote we would like to add that in 2010, a special album came out (No 27) which contains numerous lullabies and counting songs, and is titled "Wokół Dziecka. Kołysanki i pieśni dziecięce" ('Around the child. Lullabies and children songs'). The CD proved to be a musical bestseller. The value of the recordings encouraged us to share with the readers these particular lullabies, although the findings concerning the Polish folk lullaby presented in the article have been made on the basis of the material collected from the entire collection of ca 70 lullabies. We cannot quote them all here for the lack of space. 


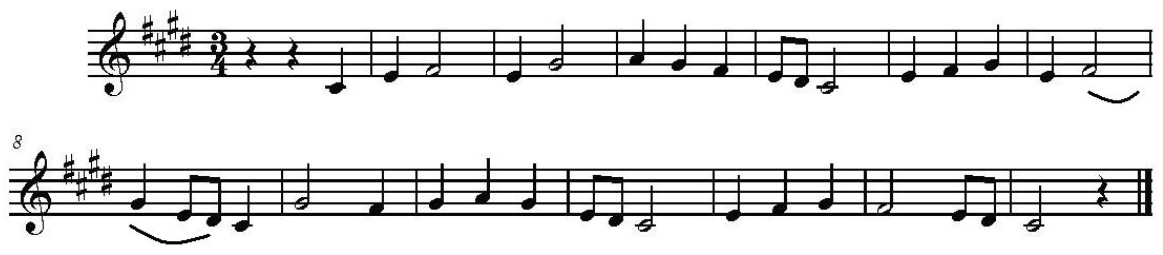

Oj lulaj, lulaj (bis)

Siwe óczka stulaj

Oj, siwe ocie stulisz

do mnie się przytulisz (bis)

Oj lulaj, lujaj/ (bis)

Maleńki sukole

Oj, jak ty mie urośniesz

Pójdziesz ze mna w pole/ (bis)

Kotysz mi się, kotysz

kolibejko lipia

Oj, niechi̇e cię, synuniu

Łóziuniu usypia/ (bis)

Kotysz mi się, kotysz

od ściany do ściany

to ja ci uwije

wianecek ruciany

Go to sleep, go to sleep

close your blue eyes

if you close your blue eyes

you'll cuddle up to me

Go to sleep, go to sleep

you little falcon

when you grow

we'll go to the field 


\section{Kazimierz Sikora \& Barbara Żebrowska}

Rock and rock

lime tree cradle

Oh, sonny boy, let

the cot put you to sleep

Rock and rock

from side to side

and I'll weave for you

a rue wreath ${ }^{3}$

Example 2. Lullaby from southern Mazovia (PRFolkColl.1).

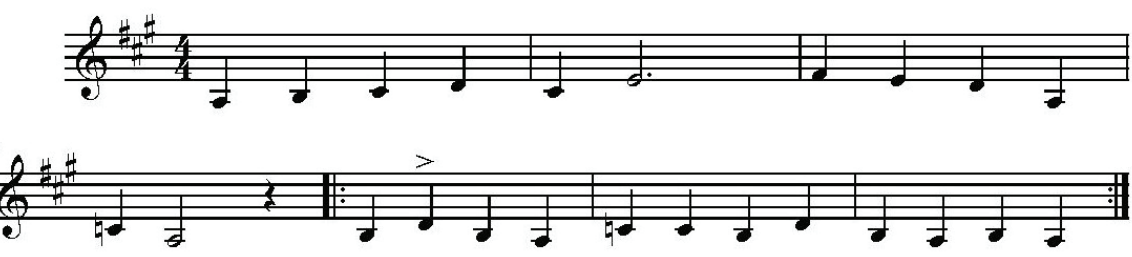

Uśnijże mi uśnij/

albo mi urośnij/

Przydasz mi się przydasz I

w pole wótki wygnasz. (bis)

Jeszczem nie urosta /

jużem się przydatal

Jużem se wóteńki /

w póleńko wygnata/ (bis)

Jeszczem nie urosta I

mamuni do kostek /

U mojej mamuni /

chtopców pełen mostek / (bis)

Jeszczem nie urosta /

mamuni do kolan /

U mojej mamuni /

Zalotniki stojo/ (bis)

3 Ruta or rue (Ruta Graveolens) - the plant believed to be connoted with female infidelity. 
Jeszczem nie urosta /

mamuni do pasa /

U mojej mamuni /

Gorzałeczki flasa / (bis)

Jeszczem nie urosta /

mamuni do szyi /

U mojej mamuni /

gorzatecke pijo/ (bis)

Do go to sleep for me, go to sleep

or grow for me

you'll be useful to me

you'll send the oxen to the field

I haven't grown yet

I am already useful

I have sent the little oxen to the field already

I haven't grown yet

to my mommy's ankles

at my mommy's place there are boys and boys

I haven't grown yet

to my mommy's knees

at my mommy's place the suitors stand

I haven't grown yet

to my mommy's waist

at my mommy's place

there's a flask of vodka

I haven't grown yet

to my mommy's neck

at my mommy's place

vodka is being drunk 
Example 3. Lullaby from Kurpie (Zielona forest; PRFolkColl.6).

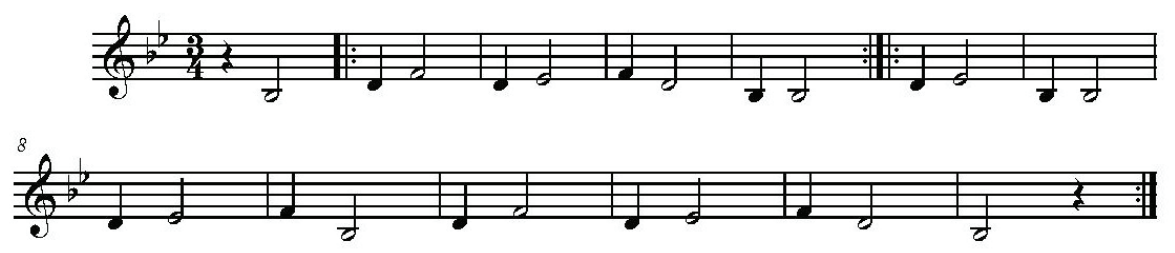

A lulaj, lulaj mate dziecie

Panu Bogu cie pol'yce

$i$ Najśwantsyj Panianecce

żebyś spało w kol'ybecc(e). (bis)

Lulaj, lulaj do ziecora

aż ci matka przyjdzie z pola.

Przyniesie ci kacke i kacor(a).

A $z$ tej kacki drobne flacki,

a z kacora duze kota.

Lulaj, lulaj moje dziecie

pojedziamy do kościo(ta).

Lulaj, lulaj do ziecora

aż ci matka przyjdzie $z$ pol(a).

Lulaj, lulaj stari hulaj,

a hulajka psiekta jåjka.

Usiadta sie na zapsiecku

psiekta jåjka w tygielec(ku). (bis)

Go to sleep, go to sleep little baby

I will entrust you to God

and the holiest Virgin

so you have your little cot to sleep in

Go to sleep, go to sleep until the evening

when your mother comes from the field

she'll bring you a duck and a gander. 
From the duck she'll make fine tripe from the gander large wheels.

Go to sleep, go to sleep my little baby we'll ride to the church.

Go to sleep go to sleep until the evening when your mother comes from the field.

Go to sleep, go to sleep, old reveller the reveller woman baked some eggs. She sat on the heated seat by the stove and baked eggs in a crucible.

\section{Lullaby - the quintessence of pragmatics and psychology}

An attempt at a definition of a lullaby must take into account the fact that lulling a baby with singing and swinging is one of the most primeval behaviours of the human being. Mothers have always done it; they lulled their child, which is an activity typical for all ethnic groups, a basic archetypical model of behaviour. This is most probably confirmed by the proto-Indo-European origin of this word stem (Pol. lulac, lulaj; Eng. lullaby; Hebrew lajla-tow, meaning 'good night'; cf. Jeziorkowska-Polakowska 2010). Another significant and persistent similarity is displayed by its narrow melodic range, slow tempo, and diversity of the verbal layer of these songs. That is why lullabies may assume an array of different forms: from monotonous iterations of onomatopoetic exclamations which occur while swinging the baby (aaa! luli luli la! etc.) to elaborate poetic forms. Lullabies can frequently be popular lyrical songs sung by adults, which are then accommodated to the situation of lulling a child to sleep. Theoretically, one could sing any song, only it has to have a "soothing power". Still, scholars emphasise that an authentic lullaby must focus on a child (the addressee of the partner in dialogue; cf. Cieślikowski 1975). Presenting an univocal definition of the lullaby is not entirely possible.

The attempts at the definition of the lullaby mention the following elements: it has a lyrical melody, the folk song is sung in 3/4 or $3 / 8$ time $^{4}$ (cf. Śmiechowski 1999). Its rhythm and melody are also argued to serve a clear purpose - that of putting the child to sleep (cf. Cieślikowski 1985). The dominant convention requires that the person putting the child to sleep sings quietly, softly and tenderly. The aim, after all, is to ensure a sense of physical and mental safety

${ }^{4}$ However, as the collected material demonstrates, this is not a necessary condition. 
for the baby, and this is based on the closeness of the loving mother. In the case of folk lullabies, it seems crucial to us that their refrains and phrases clearly harmonise with the swinging movement of the hands or the cot (or sometimes a basket hanging on a rope). It is the very swinging itself (and the equipment which is supposed to aid the swinging) that determins the rhytm and melody of the lullaby ${ }^{5}$.

Creating his own definition, Valentin Golovin draws attention to the physiology of sleep, or more specifically to its different phases. Lullabies are songs addressed at the baby who is in a transitional phase between being awake and sleeping. The songs try to help him to move from one stage into another (2000: 30). This function comprises the following elements: melody, rhythmic pattern, poetics, harmony (phonetics), motives and images which help the child to calm down, to become drowsy, melancholic, to have dreamy imagery (ibid.). From the point of view of psychology, lullaby carries an "ilinctic" function (serves the purpose of calming down the child, making it sleepy, limiting external stimuli within the reach of the baby; cf Budrewicz 1996: 280). Without such quieting, which included soothing the fears and getting rid of bad emotions, sleep will not come.

The prototypical lullaby, as has been shown in the previous examples (see above, Examples 1-3), always has the nature of oration and dialogue. But the dialogue with the infant at the breast is only apparent as it engages emotions but not intellectual reasoning. The listener, i.e. the baby, may be a partner only in an emotional sense but not the linguistic one, since it cannot participate in verbal communication. It is clear that lullabies often have the form of a concealed wish. Words have magical power - they function in accordance with magical thinking. Hence iterated commands like ‘Go to sleep, go to sleep', 'Grow, grow', 'You'll be useful to me, you'll be useful' are being sung, as seen in our examples as well. It is generally believed in Poland that one grows while asleep. Wish is a concealed directive speech act, hence in lullabies there are frequent appeals to Our Lady, Lord Jesus (as she was also a mother, and He was a child) or to various anthropomorphised objects with which the child has contact, such as its little bed, cot, pillow, or quilt. A rich repertoire of emotional and intellectual persuasion is required here.

The lullabies are to assist the mother to put the child to sleep and even if the songs are reworked and used for other purposes, they always bring the state of calm, dreaminess, melancholy or monotony ${ }^{6}$. That is why what is finally considered to be typical lullabies are those songs which have been created in order to achieve the intended effect - putting the child to sleep - and display

5 The melodies of Polish folk lullabies require a scholarly analysis, but due to insufficient documentation this might constitute a challenge for potential researchers.

6 Monotony leads to tiredness and that in turn leads to falling asleep. 
characteristic features which help reaching the aim such as dreamy imagery or a quiet monotonous melody and rhythmic pattern synchronised with the swinging movement of the cot or mother's hands.

\section{Ach, śpij, Kochanie! Putting a child to sleep in a Polish way}

\section{Creating an atmosphere which helps the child to fall asleep}

For the lullaby to meet its principle aim, it must be accompanied by other sleep-evoking elements than only those mentioned above ${ }^{7}$. What is decisive is the physical closeness of the mother and child: in the old times, the infant, for the first few days of his life, practically never left mother's arms. As it was believed, the unbaptised children can in this way only be protected from evil (Ogrodowska 2007: 62). The mother swings the baby in her arms, carries it around and talks to it. The baby cries, and mother's onomatopoetic exclamations appear spontaneously and naturally; among them echolalia, glossolalia (aaa, luli laj, alulu, cf. Budrewicz 1996: 280), humming, swinging and other instinctive and atavistic behaviours. Verbal behaviours are to sustain and enhance the baby's impression of being swung.

Another factor is the presence of the cot. The cot ideally imitates being swung in the mother's arms and appears in many lullabies. What is more, it is even occasionally addressed directly which stems from the tendency of the village population to anthropomorphise the world. In the old days, mothers weaved, sewed, cooked etc., and at the same time, pushed the rocking cot. They moved it with a leg and sang quietly when the child was crying. Alternatively, they pushed the basket in which the child was lying with the free hand. In order to take the child along to the fields where the mother was working, cots were made of thick fabric, tarpaulin, or a blanket. The cot was hung on crossed sticks or on the shaft of the horse carriage (cf. Ogrodowska 2007: 64). For the Polish peasants, the cot was the first equipment the human being needed, and was regarded as essential in taking care of a baby. That is why even in Polish carols, Messiah was put into a cot (cf. Budrewicz 1996: 278).

Persuasion contained in lullabies is evoked by several emotional strategies. They are oriented first of all to the use of the conative function of language, but also the expressive function because frequently they give rise to emotions (particularly characterising the attitude of the mother to the baby). We will classify the emotional strategies, taking into account their pragmatic aspects.

7 Of course, quieting the baby down is most important, as without it he baby cannot fall asleep. 


\section{Strategy of affective expressions and diminutives}

The presence of the strategy of affective expressions and diminutives is understandable, because scholars emphasise that the period from birth up until approximately the third year of age is the time when emotions are spontaneously and unconventionally demonstrated (cf. Sawicka 2000). A lullaby is the domain of positive emotions (love, adoration, tenderness, delight) which in the Polish language have morphological indicators - diminutives and hypocoristic names or words, even of the third degree (for example, Kaziuniuniu kochaniutenki). Affective expressions and diminutives directly enhance the persuasive function. Replacing the name with an affectonym or some other affective expression is very common practice in the Polish language. All names transform in this way, and their pleasant sound will encourage the child to fall asleep. They are abundant in lullabies and reflect the positive emotion of the singer.

\section{Strategies of argumentation}

A lullaby can also explain to the baby that it should fall asleep. Since the baby by nature desires acceptance and love, and wants the parents to be satisfied with their behaviour, then it is also able to understand that the mother must go to work (A śpijże mi, śpijże / od samego rana / bo matuś musi iść / na tąę do siana... , 'Oh sleep, oh sleep / until the morning / as mommy must go to the meadow / to get hay...'). One can persuade the baby so that it is no longer afraid of falling asleep because it will be guarded by a Guardian Angel, Our Lady, Lord Jesus, etc. (Uśnijże mi uśnij / Pan Jezus cię uśpi / aniołek obudzi / wstań Jasiu do ludzi, 'Oh fall asleep, oh fall asleep / Lord Jesus will put you to sleep / the little angel will wake you up / get up, Jasiu, and go to the people'). One can also explain to the child that it will grow faster when asleep, and that in turn would help their mother.

\section{The strategy of threatening}

Threats in Polish lullabies are rather jocular in essence, and also rather rare, but in spite of that they should be described here, as they present an interesting aspect of how to affect the baby's imagination. Most frequently, they display the schema "if you don't fall asleep, then you will be cast out of the house, into the woods, and even thrown into the river". We can see how desperate the mother of a restless baby could have been (Lulajże mi, lulaj / bo cię wrzucę $w$ dunaj / $z$ dunaja do jazu / utoniesz od razu, 'Fall asleep, fall asleep / because 
I will throw you into the river / and then from the river into the weir / you'll drown right away'). Russian lullabies tend to be frightening too - the result of which is that the child will become scared, and will become quiet, and fall asleep (Golovin 2000).

\section{The strategy of promise}

The strategy of promise consists in pointing out the reward which the baby will get when it falls asleep. It is promised something good to eat, or alternatively an object or an animal to play with, or some other pleasant activity. Both the threat and the promise may be used, i.e. the stick and the carrot (Śpij dzieciatko śpij / dam ci jabtka trzy / a jak jabłka nie pomoga / to pomoże kij!, 'Sleep baby sleep / I will give you three apples / and if the apples don't help / a stick will!'; a Silesian lullaby).

\section{Strategy of evoking sympathy and empathy}

The strategy of evoking sympathy and empathy is usually tied to the tiredness of the mother, lack of time for herself, the sense of being abandoned, and loneliness. In the old days, a young mother never left the house for even as long as six weeks until the religious purification ritual took place in the church. But in fact it was the very social role of the housewife and mother that tore her away from the pleasures of life (cf. Ogrodowska 2007: 42-45). Hence the complaining about their fate and longing for freedom and pleasures of life.

While persuading the baby to fall asleep, the emotional tactics typical of the lullabies were used, but if even these failed to work, more radical means were resorted to, sometimes even dangerous ones. For example, a crying baby was given vodka or extract from poppy seeds; also various magical rituals were carried out (Ogrodowska 2007: 75). In lullabies, many ambiguous symbols of ancient agrarian culture are present, whose meanings, probably magical, we can understand.

As a final example, I would like to present one of the most popular Polish folk lullaby in the version noted down in the environs of Kraków:

Uśnijże mi, uśnij,

Pan Jezus cię uśpi, aniołek obudzi, pójdziemy do ludzi. 
Uśnijże mi, uśnij, albo mi urośnij, prędzej ty mi uśniesz niżeli urośniesz.

Uśnijże mi, uśnij, prędko mi urośnij, możesz mi się przydać w pole gaski wygnać.

A śpijże mi, śpijże od samego rana, bo matuś musi iść na tąke do siana Uśnijże mi, uśnij, dziecię kochające, a nie obudź mi się,

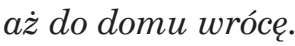

Uśnijże mi, uśnij, choć na gołej ziemi, bo ci cyganeczki poduszeczkę wzieni.

Lulajże mi, lulaj, siwe oczka stulaj, siwe siwiusieńkie, dziecię malusieńkie.

Do go to sleep, go to sleep for me Lord Jesus will put you to sleep A little angel will wake you up We will go see people

Do go to sleep, go to sleep for me Or grow for me You will fall asleep faster than you will grow

Do go to sleep, go to sleep for me Grow fast for me You will be useful to me to let the geese out into the field 
Oh sleep for me, oh sleep for me from the very morning as your mommy must go to the meadow to make hay.

Do go to sleep, go to sleep for me my loving baby and do not wake up for me until I get home

Do go to sleep, go to sleep for me even on the bare ground as the little Gypsy girls have stolen your pillow from you

Do go to sleep for me, go to sleep

Close your little blue eyes

The bluest

my tiny tiny baby

(Płatek 1976)

\section{References}

Budrewicz, Tadeusz 1996. Najpiękniejsza kołysanka polska (o "Lulajże, Jezuniu"). [The most beautiful Polish lullaby (on "Lulajze, Jezuniu").] In: T. Budrewicz \& S. Koziara \& J. Okoń (eds.) Z kolęda przez wieki. Kolędy w Polsce i krajach stowiańskich [With the carol across the ages. Carols in Poland and the Slavic countries]. Tarnów: Biblos, pp. 272-284.

Cieślikowski, Jerzy 1975. Literatura i podkultura dziecięca. [Literature and subculture of children.] Wrocław: Zakład Narodowy im. Ossolińskich-Wydawnictwo.

Cieślikowski, Jerzy. 1985. Literatura osobna. [Separate literature.] Warszawa: Nasza Księgarnia.

Golovin, Valentin 2000 = Головин, Валентин 2000. Русская кольбельная песня в больклоре и литературе. [Russian lullabies in folklore and literature.] Turku: Ábo Akademi University Press.

Jeziorkowska-Polakowska, Anna 2010. Pieśni zaklęte $w$ dwa języki... [Songs cast in two languages.] Lublin: Wydawnictwo Towarzystwo Naukowe KUL.

Ogrodowska, Barbara 2007. Polskie tradycje i obyczaje rodzinne. [Polish family traditions and customs.] Warszawa: Sport I Turystyka. 


\section{Kazimierz Sikora \& Barbara Żebrowska}

Płatek, Piotr 1976. Albośmy to jacy tacy. Zbiór pieśni Krakowiaków Wschodnich i Zachodnich. [We are not just anyone. Songs of Eastern and Western Crakovians.] Kraków: Krajowa Agencja Wydawnicza.

Sarv, Mari 2013. Traditional Estonian lullabies. A tentative overview. In: L. Laineste \& D. Brzozowska \& W. Chłopicki (eds.) Estonia and Poland: Creativity and tradition in cultural communication, Vol. 2: Perspectives on national and regional identity. Tartu: ELM Scholarly Press, pp. 161-176.

Sawicka, Grażyna 2000. Miłość niejedno ma imię (Językowe i pozajęzykowe interakcje między matką a dzieckiem). [Love has more than one name (Linguistic and extra-linguistic interactions between a mother and a child).] In: I. Nowakowska-Kempna \& A. Dąbrowska \& J. Anusiewicz (eds.) Język a Kultura [Language and culture], Vol. 14, Uczucia $w$ języku $i$ w tekście. [Feelings in language and text.] Wrocław: Uniwersytet Wrocławski, pp. 153-163.

Śmiechowski, Bogusław 1999. O muzyce najpiękniejszej ze sztuk. [On music, the most beautiful of arts.] Warszawa: Adam. 